\title{
Kim był David Cameron? Sylwetka polityczna byłego premiera
}

https://doi.org/10.25312/2391-5129.32/2021_10bw

\begin{abstract}
Artykuł ukazuje sylwetkę Davida Camerona jako polityka i jako osobliwości. Zamiarem autora było również ukazanie tez dotyczących pragmatyczności polityki Camerona. Zwrócono uwagę na fakt odejścia torysów od linii politycznej Margaret Thatcher za sprawą nowego premiera i skierowania działań Wielkiej Brytanii w zupełnie inne obszary polityki wewnętrznej i zagranicznej. Pobocznym celem jest zasygnalizowanie konsekwencji polityki Camerona dla otoczenia zewnętrznego, przede wszystkim spójności Unii Europejskiej, a także - w kontekście polityki imigracyjnej - dla krajów młodej Unii.
\end{abstract}

Słowa kluczowe: David Cameron, sylwetka polityczna, premier, poglądy, reformy

\section{Wstęp}

Obecna sytuacja zarówno polityczna, jak i zdrowotna (pandemia COVID-19) doprowadziła do nasilenia dyskusji o przyszłości Unii Europejskiej, a także miejsca i roli, jaką odgrywać w niej ma i będzie Zjednoczone Królestwo po opuszczeniu unijnych struktur. Rodzące się liczne pytania dotyczące tak ważnej tematyki skłoniły do przypomnienia sylwetki Davida Camerona - polityka, za rządów którego doszło do referendum w sprawie członkostwa Wielkiej Brytanii w Unii Europejskiej. Nadmienić należy, że postać ówczesnego premiera budziła bardzo mieszane uczucia tak wśród konserwatystów, jak i liberałów. Skąd wzięły się kontrowersje w postrzeganiu premiera? Choćby stąd, iż z jednej strony (jako lider torysów) popierał związki jednopłciowe i mówił o sobie, że jest wielkim fanem Margaret Thatcher, z drugiej zaś zawiązywał koalicję z liberalnymi demokratami.

\footnotetext{
* Mgr Bernard Wardziński - Akademia Finansów i Biznesu Vistula Pułtusk.
} 


\section{Thatcheryzm Davida Camerona}

O zachwycie postacią Margaret Thatcher świadczyć może słynna kwietniowa mowa Camerona z 2013 roku w Parlamencie, podczas której chwalił niezłomną wolę byłej pani premier oraz jej konserwatywno-liberalny program. Skonstatował, że ,wszyscy jesteśmy thatcherystami”, co miało między innymi ostudzić konflikty w jego ugrupowaniu, bowiem dla wielu konserwatystów Thatcher była i wciąż jest symbolem sukcesu politycznego, zaś Cameron uważany był za tego, który te ideały (konserwatywne) sprzeniewierzył. Nieprzychylni Cameronowi konserwatyści w rządzie twierdzili nawet, że premier przekształcił torysów w Blue Labour - niebieską (to kolor torysów) Partię Pracy, ślepo naśladując wcześniejsze sztuczki polityczno-propagandowe Tony'ego Blaira.

W przeciwieństwie do Thatcher hamował przymus sprawowania koalicyjnych rządów z Liberalnymi Demokratami. Jednocześnie - tak jak większość współczesnych europejskich liderów partii rządzących - usiłował poszukiwać centrowego środka i kreować wizerunek Partii Konserwatywnej, tak by trafić do jak największego elektoratu. Cameron zrozumiał, że restrykcyjny i nieustępliwy tryb rządzenia Thatcher, mający na celu rozmontowanie zbudowanego po wojnie państwa opiekuńczego, obecnie był niemożliwy. Podważenie pozycji związków zawodowych na Wyspach sprawiło, że ostra retoryka mogła być co najwyżej skierowana przeciwko imigrantom i klasie posiadającej, co z kolei i w jednym, i w drugim wypadku mogło przynieść więcej szkód niż korzyści w wyborach w 2015 roku. Zamiast odwoływać się do jakiegoś konkretnego punktu programu swej poprzedniczki Cameron próbował odwoływać się do Thatcher jako postaci charyzmatycznej liderki, której cechy rzekomo on również posiadał.

Wydaje się, że Cameron poprzez nawiązania do Thatcher jako charyzmatycznego polityka starał się wyciszać przeciwników w swojej własnej partii i zyskiwać społeczne poparcie. W takich kwestiach, jak reforma związków zawodowych czy prywatyzacja własności państwowej odwoływał się do potocznie akceptowanego neoliberalnego światopoglądu, ale w kwestiach najważniejszych, takich jak reforma szkolnictwa, systemu emerytalnego oraz członkostwo w UE nie miał już tak konserwatywnego zdania.

Jak już wspomniano, Cameron usiłował stworzyć logiczny przekaz, który zawierałby w sobie Thatcherowską nieugiętość w sprawach ekonomicznych, a jednocześnie łagodność modernizacyjnego podejścia zawartego w jego wyborczym projekcie „Wielkie społeczeństwo” z roku 2010. Pragnienie intensywnej reformy społecznej w niewielkim stopniu dawało się jednak pogodzić ze słynnymi słowami Thatcher o tym, że „nie istnieje coś takiego jak społeczeństwo”. Było tak dlatego, że choć w kwestiach ekonomicznych panuje na Wyspach prawicowy konsensus i Cameron nie chciał go naruszać, to w kwestiach społecznych stosował już o wiele łagodniejszą retorykę i w zasadzie zachował wiele z rozwiązań, które wprowadzili Tony Blair czy Gordon Brown. 


\section{Sylwetka polityczna Davida Camerona}

Duże znaczenie dla przyszłego premiera miała próba odnowienia w 2005 roku oblicza Partii Konserwatywnej. W nawiązaniu do niej byli rywale Camerona, David Davis oraz Liam Fox, postawili na nowoczesny konserwatyzm, natomiast on sam zasugerował ideę konserwatyzmu współczującego. Teoria ta, eksponująca zagadnienia społeczne, skupiała się również na ociepleniu wizerunku lidera partii. Musiano tak postąpić, ponieważ wielu członków partii uważało biografię Camerona za mijającą się ze stylem życia przeciętnego obywatela. Sylwetka Camerona, absolwenta Eton i Oxfordu, wywodzącego się przecież jak by nie było z uprzywilejowanej klasy społecznej, budziła skrajne odczucia i emocje. Wielu członków Partii Konserwatywnej wychodziło z założenia, iż powoływanie go na przewodniczącego było krokiem wstecz (ostatni przewodniczący wywodzący się z wyższej klasy społecznej sprawował władzę w latach 1963-1964).

Nadmienić należy, że wygrana Davida Camerona w wyborach wyłaniających lidera Partii Konserwatywnej sygnalizowała zwrot jej ideologicznego kursu. Podczas swych przemówień nowy przewodniczący ustawicznie eksponował pragnienie transformacji i odnowienia polityki torysów. Dlatego też zapożyczył od socjaldemokracji idee polityczne wzywające do walki ze społeczną niesprawiedliwością. Niemniej jednak sukces Partii Pracy opierający się w dużym stopniu na podążaniu w kierunku ideowych zamierzeń Thatcher pod sztandarem „sprawiedliwości społecznej” i ,gospodarczej efektywności” zdeformował dotychczasowe podziały ideologiczne (Dulęba, 2012: 203). Cameron zmierzał do zaadaptowania stylu laburzystów, mając przekonanie o skuteczności części doktryny New Labour (Lee, 2009: 6). Osobiście porównał się do spadkobiercy Blaira (heir to Blair), odnosząc się do laburzystowskiego powrotu thatcheryzmu, a w szczególności stylu komunikacji społecznej (Elliott, Hanning, 2012: 297).

Ideologia „współczującego konserwatyzmu” formowała się od chwili zapoczątkowania kampanii wyborczej Camerona na lidera Partii Konserwatywnej do proklamowania manifestu partyjnego Bulit to Last w 2006 roku. Według Camerona usunięcie biedy winno być następstwem wzrostu gospodarczego państwa, jednakże nie przez narzędzia redystrybucyjne, ale poprzez wdrożenie mechanizmów opierających się na zasadzie „laissez faire”. Takie podejście charakteryzowało thatcheryzm. Dlatego też wbrew sygnalizowanemu w partii przełomowi polityka torysów nie uległa zmianie i nie przyniosła odrzucenia doktryny thatcheryzmu.

Ważną kwestią zwracającą uwagę było upowszechnienie (podczas kongresu w Manchesterze w kwietniu 2006 roku) przez Camerona „kodeksu” nowych konserwatystów. Zaproponował w nim na przykład w miejsce jazdy prywatnym samochodem poruszanie się komunikacją publiczną. Zasugerował także, żeby poznawać swych sąsiadów, podnosić z ziemi śmieci, a zakupów nie pakować do tak zwanych jednorazówek. Zakupy zalecał robić w lokalnych sklepikach, a także zmieniać żarówki na energooszczędne. Znaczenie tej rewolucji w pełni docenić można wtedy, gdy pa- 
mięta się słowa Margaret Thatcher stwierdzające, że ten, kto po 26. roku życia wciąż musi poruszać się komunikacją miejską, może uważać swe życie za wielką klapę.

Pod koniec 2009 roku D. Cameron przedstawił pomysł na nowe funkcjonowania rządu. W jego koncepcji rola centralnego rządu miała zostać ograniczona na rzecz wspólnot lokalnych. Cameron dobitnie eksponował społeczny charakter własnego programu politycznego oraz jego cel, czyli ograniczenie ubóstwa, zwalczanie nierówności społecznych, a także zwiększenie dobrobytu społeczeństwa. Według niego rozrost administracji rządowej wywołał dezintegrację społeczeństwa, a nadmiernie powiększony (za rządów Partii Pracy) aparat polityki społecznej odebrał Brytyjczykom społeczną i osobistą odpowiedzialność (Cameron, 2010b). Program ten, zwany Big Society, został wdrożony po zwycięskich wyborach Camerona.

Zauważyć należy, iż Partia Konserwatywna pod przywództwem Davida Camerona przeprowadziła zasadnicze modyfikacje programowe, które miały tyle wspólnego $\mathrm{z}$ tradycją konserwatyzmu, co blairyzm z tradycją socjalizmu. Reforma Camerona obejmowała tak sporne kwestie, jak ekologia, pomoc społeczna (opieka medyczna), stosunek wobec kwestii gender (postrzeganej do tej pory jako feminizm), mniejszości seksualnych. Przeorientowaniu uległ także stosunek konserwatystów do podatków i aktywnej polityki państwa w gospodarce (Dorey, 2007: 141). Koncepcja „,wielkiego społeczeństwa" (Big Society), ukształtowana podczas wyborów parlamentarnych 2010 roku, była postrzegana zarówno jako nawiązanie do Disraelowskiej koncepcji jednego narodu (one nation), jak i swoista formuła konserwatywnej „trzeciej drogi” - opierająca się na poszukiwaniu wyważonego stanowiska pomiędzy wszechpotężnym państwem a skolektywizowanym społeczeństwem (Zuba, 2012: 110).

Ideologiczny charakter Partii Konserwatywnej ulegał przeobrażeniu. Z jednej strony David Cameron utrzymywał retorykę współczującego konserwatyzmu, z drugiej zaś instrumenty, za pomocą których eliminował problemy społeczne i gospodarcze przypominały działania rządów M. Thatcher i jej kanclerza Keitha Josepha. Przedstawiając program Big Society, Cameron pozwolił poznać się w charakterze działacza politycznego wspierającego niezależne ruchy partycypacyjne i rozpowszechniającego wymóg rozszerzenia prerogatyw organizacji pozarządowych.

Przypominając sylwetkę Davida Camerona jako polityka, w pierwszej kolejności należy poruszyć problematykę dotycząca jego pochodzenia, poglądów a także sposobu dojścia do władzy. Choć biografia Camerona wydaje się typowa, dostrzec w niej możemy ciekawe i interesujące wątki. Jednym z nich jest pochodzenie byłego premiera Wielkiej Brytanii. Oficjalne źródła podają, że pochodzi z bardzo zamożnej angielskiej rodziny, a jednym z jego przodków był król Wielkiej Brytanii Wilhelm IV Hanowerski. Jednak pomimo że w żyłach Camerona płynęła szkocka krew, to emocjonalnie uczestniczył on w poczynaniach, które przeciwstawiały się tendencjom separacyjnym Szkotów.

Ten 78. premier Wielkiej Brytanii odebrał bardzo staranne wykształcenie. Ukończył elitarną i najdroższą prywatną szkołę - Eton College. W trakcie nauki nie był 
postrzegany jako wielki naukowiec czy osoba interesująca się polityką i podczas pobytu w murach uczelni nie zajmował się on bynajmniej tylko nauką. Kiedy w niej przebywał, został między innymi przyłapany na zażywaniu narkotyków, a w konsekwencji wplątany w największy skandal w tejże placówce.

Według internetowego wydania tygodnika „Mail on Sunday” Cameron w wieku 15 lat z trudem uniknął wydalenia z Eton, gdy władze szkoły nakryły na paleniu marihuany grupę uczniów i powiadomiły policję, która przeprowadziła oficjalne śledztwo. Siedmiu uczniów zostało wówczas wyrzuconych z tej elitarnej, połączonej z internatem szkoły dla chłopców, która od pokoleń uznawana była za kuźnię kadr dla brytyjskiego państwa i finansjery (Brytyjski polityk bohaterem skandalu z marihuana, 2007). Po ujawnieniu tej informacji Cameron przyznał: „Jak wiele osób, robiłem w młodości wiele rzeczy, których nie powinienem robić i których żałuję" (Ostrowski, 2014).

Po tym incydencie Cameron na rok przerwał swoją przygodę z nauką, rozpoczął pracę w znanej brytyjskiej korporacji Sussex MP Tim Rathbone, spędził trzy miesiące w Hongkongu, pracując dla spedytora, a następnie powrócił koleją przez ZSRR i Europę Wschodnią. Jak sam przyznał w wywiadzie dla BBC Radio 4 w Desert Island Discs ,przesłuchiwało” go w Jałcie KGB w celach rekrutacji. Ten fakt opisywał w sposób następujący: „Spotkałem znajomego w Moskwie i udaliśmy się do Jałty na wybrzeże Morza Czarnego, gdzie spotkaliśmy dwóch Rosjan mówiących «doskonale po angielsku», którzy pojawili się na plaży głównie odwiedzanej przez cudzoziemców. Zabrali nas na kolację i przesłuchiwali w przyjazny sposób, pytając o życie w Anglii i co myślimy o polityce. Byliśmy oczywiście ostrożni w odpowiedziach. Dopiero jak dostałem się na uniwersytet, uświadomiłem sobie, że mogła to być próba zwerbowania przez KGB” (Cameron, 2006).

Po powrocie Cameron rozpoczął studia w Brasenose College na Uniwersytecie Oksfordzkim. Część prasy brytyjskiej do dzisiejszego dnia zarzuca mu, iż zbytnio chełpi się swoim oksfordzkim wykształceniem, pomimo że zakończył swoją karierę naukową zaledwie na tytule licencjata kierunku PPE (filozofii, politologii i ekonomii) i nie kontynuował nauki aż do momentu uzyskania stopnia doktora (PhD). Niemniej pretensje te wydają się przesadzone (David Cameron, 2013). Cameron ukończył bowiem tę uczelnię w 1988 roku z dyplomem pierwszej klasy, a jeden z jego profesorów, Vernon Bogdanor, określił go mianem najzdolniejszego studenta o poglądach umiarkowanie konserwatywnych (Wheeler, 2005).

Jak już wspomniano, podczas studiów Camerona interesowała nie tylko nauka. Brał on udział w spotkaniach wielu klubów studenckich. Czynnie udzielał się w elitarnym Bullingdon Club, klubie zrzeszającym wyłącznie mężczyzn, którego członkowie mówią o sobie „Buller”, ubierają się we fraki, noszą się wyniośle i upijają się w drogich restauracjach, rezerwując miejsca pod fikcyjnym nazwiskiem. Tradycją „Bullerów” było kończenie imprez demolowaniem lokali, choć zawsze pokrywali oni koszty szkód. Stowarzyszenie to wzbudzało duże kontrowersje z powodu 
konsumpcji dużej ilości alkoholu i bujnego życia towarzyskiego. Warunkiem wstępu do tegoż ekskluzywnego i elitarnego klubu był status materialny jego przyszłego członka. Jeden z bloggerów „Financial Times” 5 kwietnia 2010 roku zarzucił liderowi opozycyjnej Partii Konserwatystów Davidowi Cameronowi, że w okresie studiów w Oksfordzie w latach osiemdziesiątych uczestniczył w pijackim demolowaniu restauracji w 1987 roku. Gazeta powoływała się na przyjaciela z czasów studenckich Camerona, również członka klubu, dla którego nie ulega wątpliwości, iż był on uczestnikiem rozróby. Przyszły premier uniknął zatrzymania przez policję, ponieważ udało mu się uciec. Jednak stanowczo zaprzeczał tym doniesieniom, twierdząc, że tego dnia położył się wcześnie spać. Z kolei inny prominentny były „Buller” burmistrz Londynu Boris Johnson nigdy nie ukrywał, iż brał udział w incydencie. Jednak wbrew jego własnym słowom nie został wówczas aresztowany, lecz wraz z Cameronem i trzecim studentem zdołał umknąć policji. Pozostali członkowie ekskluzywnego klubu spędzili noc na posterunku wyłapani w ogrodzie botanicznym jeden po drugim przez policyjne psy. Sygnałem do demolowania oksfordzkiej restauracji było wybicie okna doniczką. Jak zauważał ironicznie komentator „Financial Times”, trzech uciekinierów to także ludzie, którzy byli absolwentami elitarnej szkoły prywatnej Eton College i - tak jak w przypadku Camerona i Johnsona - również zrobili największe polityczne kariery, zostając posłami Izby Gmin w 2001 roku (Nowicki, 2015). Nie dziwi więc fakt, że Cameron milczy, powołując się na prawo do życia prywatnego odnośnie do wydarzeń rozgrywających się w klubach, ponieważ pokazywał w nich, co to znaczy mieć „mocną głowę”.

Po ukończeniu studiów w 1988 roku Cameron rozpoczął pracę w departamencie badawczym Partii Konserwatywnej. Podczas swej czteroletniej pracy postrzegany był jako zdolny, sumienny i energiczny młody człowiek. W 1992 roku został specjalnym doradcą rządu, początkowo w Ministerstwie Skarbu, gdzie zajmował się między innymi przygotowywaniem wystąpień medialnych dla ówczesnego ministra, a później w Ministerstwie Spraw Wewnętrznych. Przed poświęceniem się wyłącznie karierze politycznej zebrał doświadczenie w biznesie i administracji. Spędził siedem lat w Carlton Communications, która jest jedną z wiodących brytyjskich firm medialnych na wyspach. Kierował tam działem promocji oraz zasiadał we władzach wyżej wymienionej firmy. Jego zagorzali przeciwnicy zarzucali mu później to, że zaczął interesować się polityką w momencie, gdy nie wyszła mu kariera bankowca. Niemniej doświadczenie w biznesie pozwoliło przyszłemu premierowi poznać, co to znaczy biurokracja, wysokie podatki, i uświadomić potrzebę tworzenia nowych miejsc pracy. Dzięki tym doświadczeniom, a także późniejszym w administracji i biznesie zyskał uznanie środowiska przemysłowców (Gach).

Karierę polityczną Cameron rozpoczął od pierwszej nieudanej próby dostania się (w 1997 roku) do Izby Gmin z okręgu Stafford. Dopiero dzięki drugiej próbie (po czterech latach) zdołał wygrać wybory w okręgu Witney i stać się reprezentantem okręgu w Izbie Gmin. Wszedł wówczas w skład parlamentarnej komisji spraw we- 
wnętrznych. W szybkim tempie z szeregowego deputowanego stał się wybijającym się politykiem Partii Konserwatywnej.

W 2003 roku został wiceprzewodniczącym Partii Konserwatywnej, a rok później głównym rzecznikiem (speakerem) konserwatystów w sprawach dotyczących samorządu lokalnego. W dość krótkim czasie otrzymał propozycję objęcia posady ministra edukacji w gabinecie cieni.

Po kolejnej porażce konserwatystów w wyborach w maju 2005 roku ze stanowiska lidera partii zrezygnował Michael Howard. Wtedy to - 29 września - Cameron zgłosił swoją kandydaturę. Zyskał poparcie innego wiceprzewodniczącego partii, Michaela Ancrama, byłego lidera konserwatystów Williama Hague’a, Kanclerza Skarbu w gabinecie cieni George' a Osborne'a oraz Olivera Letwina i Borisa Johnsona. W swojej deklaracji Cameron ogłosił dążenie do stanu, aby ludzie znów byli dumni z faktu bycia konserwatystami. Pierwsza tura wyborów na przewodniczącego partii była zaskoczeniem zarówno dla deputowanych, jak i samego Camerona, bowiem w wyniku głosowania otrzymał 56 głosów, co dawało mu miejsce drugie zaraz po D. Davisie. Dwa dni później (20 października) uzyskał już 90 głosów, zaś trzecią turę Cameron wygrał zdecydowaną większością (78\%). Jego wybór na przewodniczącego Partii Konserwatywnej i jednocześnie lidera opozycji został ogłoszony 6 grudnia.

\section{Poglądy Camerona o roli Wielkiej Brytanii we Wspólnocie}

Po wygranej nowy lider torysów zapowiedział „modernizację” partii, która powinna jego zdaniem reprezentować „nowoczesny”, bliski obywatelom konserwatyzm, a jednocześnie stanowić „konstruktywną opozycję”. Rozpoczynając kampanię, wskazywał, że należy dokonać zmian, aby wygrać. Z kolei po wygranych wyborach dowodził, że partia, której jest liderem, musi zmieniać się dalej. Zmiany są konieczne, by uzyskać zaufanie ludzi.

Już w trakcie kampanii zasugerował wycofanie Partii Konserwatywnej z najsilniejszej frakcji w Parlamencie Europejskim - Europejskiej Partii Ludowej, uznając ją za zbyt przychylną integracji. Cameron był generalnie przeciwny przyjęciu konstytucji europejskiej i apelował, by UE zaangażowała się w liberalizację handlu światowego. „Przed Unią Europejską jest optymistyczna, pełna nadziei przyszłość, ale przed Unią poszerzoną, elastyczną i sprawiedliwą, bez kluczowych kompetencji w zakresie regulacji socjalnych i zatrudnienia, które są tak szkodliwe dla brytyjskiego biznesu" (Widzyk, 2005) - tymi słowami Cameron wyraził swoje myśli dotyczące UE.

Liczni obserwatorzy jego rozwijającej się kariery byli zdania, iż Cameron miał dużą szansę na zmianę obrazu partii, która uważana była za skostniałą i mało zdecydowaną. Już wtedy Cameron stał się dla Partii Konserwatystów „zastrzykiem energii”, tak jak 41-letni Tony Blair dla Partii Pracy w 1994 roku. Stąd też do Camerona przylgnął przydomek ,Tory Blair”. 
Co charakterystyczne, po wygranych wyborach Cameron odszedł w znacznym stopniu od tradycyjnego programu konserwatystów, wprowadzając do niego wiele zmian. Tradycyjni konserwatyści nie mogli mu wybaczyć, że przesunął partię do centrum, że postawił na ekologię i popierał walkę z globalnym ociepleniem. Wzburzenie prawicy konserwatywnej wywołało ostateczne otwarcie partii na gejów i lesbijki oraz słowa przeprosin za dyskryminację w czasach premier Margaret Thatcher.

10 maja 2010 roku, po złożeniu dymisji przez Gordona Browna, królowa Elżbieta II powierzyła Davidowi Cameronowi misję utworzenia nowego rządu.

Rządzący od maja 2010 roku Wielką Brytanią David Cameron nie był postrzegany jako mąż stanu na miarę Churchilla. Nie można mu jednak odmówić, że sztukę przetrwania opanował do perfekcji. Kiedy trzeba, umiał się wycofać - jak zrobił to w lutym 2011 roku, wstrzymując prywatyzację części lasów państwowych w Anglii. Cameron miał niezwykłą wprost zdolność wychodzenia cało z afer, które innych polityków mogłyby kosztować karierę. Niemal każdą sprytnie gasił zapowiedziami publicznych dochodzeń i daleko idących reform. Odbierał tym oręż coraz bardziej bezsilnej opozycji. I zwodził opinię publiczną...

Cameron był konserwatystą nowego gatunku. Stanowił wręcz przeciwieństwo Margaret Thatcher, która na wewnętrznym froncie nieustannie wietrzyła partyjne spiski, wojowała z ministrami, zaś na zewnętrznym wściekle prywatyzowała. Cameron, jeszcze zanim został premierem - jak już wspomniano - przeprosił w 2009 roku gejów za wprowadzone przez Thatcher w 1988 roku przepisy zabraniające promowania homoseksualizmu w szkołach. By skutecznie rządzić, nie wahał się wejść w koalicję z Liberalnymi Demokratami, mimo iż był świadom sprzeczności interesów w wielu kwestiach (między innymi polityce europejskiej). Ta rzadka jak na brytyjskie standardy koalicja, której nikt na początku nie dawał wielkich szans, przetrwała całą kadencję. Co więcej, torysi zdołali „urobić” w wielu sprawach liberałów.

Mimo wielkiego oporu społecznego Cameron forsował reformę publicznej służby zdrowia (NHS), uchodzącej na Wyspach za świętą krowę. Wszystkie związki lekarskie i większość Brytyjczyków były przeciwne zmianom prowadzącym do cięć w biurokracji i do prywatyzacji usług medycznych finansowanych z publicznej kasy. Cameron upierał się jednak przy nich, twierdząc, że kraju nie stać na utrzymanie status quo.

Wbrew kościołowi - i tradycyjnej linii swej partii z lat osiemdziesiątych i dziewięćdziesiątych - doprowadził do zalegalizowania małżeństw homoseksualnych (Pawlicki, 2012). David Cameron mimo swojej przynależności do brytyjskiego establishmentu i majątku sięgającego 30 milionów funtów budził szacunek wśród zwykłych obywateli. Łatwo nawiązywał kontakt ze zwykłymi obywatelami, nie wykazywał wobec nich poczucia wyższości. Przemawiał za nim fakt, że mieszkał w jednej z modniejszych dzielnic Londynu - Notting Hill, gdzie (oczywiście zanim został premierem) można go było często spotkać jadącego do pracy na rowerze (Rybarczyk, 2010).

David Cameron w pierwszym okresie sprawowania władzy deprecjonował znaczenie kwestii europejskiej w brytyjskiej agendzie politycznej, zarzucając niektórym 
politykom ich „,europejską obsesję”. Dopiero dwa obustronnie powiązane zdarzenia wymogły na nim potrzebę stanowczej reakcji. Pierwsze dotyczyło tzw. backbenchers w Partii Konserwatywnej, drugie zaś miało związek ze wzrostem poparcia eurosceptycznej partii UKIP. Jak wskazywały badania, notowania UKIP rosły kosztem poparcia dla Partii Konserwatywnej.

Wobec wyzwań i zagrożeń Cameron stanął na stanowisku, że cele strategiczne integracji europejskiej związane z konsolidacją Zachodu w czasie „zimnej wojny”, a także zapobieganie konfliktom w Europie Zachodniej, zostały osiągnięte.

Założenia polityki Camerona wobec Unii Europejskiej stanowiły potwierdzenie wyrażonej już wcześniej opinii, że podejście Brytyjczyków do problemu integracyjności cechowała typowa postawa wyspiarska, oparta na obronie własnej niezależności.

Nasilający się dylemat europejski (eurosceptycyzm) sprowokował Camerona do podjęcia prób jego rozwiązania poprzez przygotowanie odpowiednich projektów politycznych. I tak w pierwszym Cameron zobowiązał się do przeprowadzenia referendum w sprawie dalszego członkostwa Zjednoczonego Królestwa w Unii Europejskiej w 2017 roku, jeżeli Partia Konserwatywna wygra kolejne wybory powszechne do parlamentu w 2015 roku. Drugi zaś to wolno odkrywana wizja reformy Unii Europejskiej. Obie koncepcje posiadały wspólny mianownik - referendum ma dotyczyć członkostwa na nowych zasadach, wynegocjowanych przez Zjednoczone Królestwo zgodnie z założeniami reformy. Przeciwnicy Camerona traktowali jego zapowiedzi jako mało realne i dlatego między innymi zgodzili się na przyjęcie ustawy o organizacji referendum, która stanowiła zapewnienie, że premier nie wycofa się z obietnicy po ewentualnym zwycięstwie w wyborach.

Osobistą koncepcję reformy Unii Europejskiej David Cameron osnuł na ocenie doniosłych dylematów, z którymi zmaga się Unia. Według niego zgubne oddziaływanie na funkcjonowanie Unii miała stagnacja strefy euro, która nadwyrężyła stabilność zarazem gospodarczą; jak i polityczną państw członkowskich. Kolejnymi bolączkami były: stan gospodarek i konkurencyjność państw UE, uzyskujących coraz niższe notowania w porównaniu do gospodarek państw azjatyckich czy amerykańskich. Powodem ułomności Unii stawał się również rozdźwięk między mieszkańcami a urzędami UE. Cameron zwracał uwagę na niedobór demokracji i zbytnie oddalenie organów decyzyjnych, to znaczy wzmocnienie instytucji europejskich, o słabej demokratycznej legitymacji kosztem instytucji narodowych, w szczególności parlamentów (Czapniewski, 2013: 3). Zdaniem premiera Wielkiej Brytanii, jeżeli UE wspólnie nie stawi czoła tym wyzwaniom, ,istnieje niebezpieczeństwo, iż Europa zawiedzie, zaś naród brytyjski będzie dryfował ku opuszczeniu UE”. Premier podkreślał, iż nie chciał, aby ta ewentualność stała się faktem: „Chcę, aby Unia Europejska była sukcesem. Chcę też, aby relacje pomiędzy Wielką Brytanią a UE sprawiały, że będziemy chcieli w Unii pozostać” (EU speech at Bloomberg, 2013).

Przypatrując się powyższej koncepcji, możemy stwierdzić, że nie była ona zbyt oryginalna, bowiem wspomniane zagadnienia były i są od dłuższego czasu 
problemami debaty politycznej, jak i refleksji naukowej. Wyobrażenie reform Camerona było również dość ogólnikowe. Posiłkował się pięcioma założeniami raczej skąpo uszczegółowionymi. Zaliczyć do nich możemy: poprawę konkurencyjności (wzmacnianie zdolności UE oraz jej państw członkowskich do skutecznego uczestnictwa w globalnej wymianie gospodarczej), elastyczność - flexibility (przekształcanie Unii w strukturę typu sieciowego, nie zaś zhierarchizowaną strukturę blokową), demokratyczną odpowiedzialność - accountability (zwiększenie roli demokratycznych instytucji narodowych w kontrolowaniu i kreowaniu polityk unijnych), obustronny przepływ kompetencji między parlamentami narodowymi a instytucjami narodowymi oraz sprawiedliwość - faimess (utrzymanie jednakowego dostępu na uczciwych zasadach do jednolitego rynku europejskiego dla wszystkich państw zarówno strefy euro, jak i pozostających poza nią) (Biskup, 2013: 5-6).

Według Camerona kluczowa dla reformy UE miała być zasada sprawiedliwości. Lider torysów podkreślał szczególną wagę tej zasady dla Wielkiej Brytanii, która nie zamierzała przystępować do wspólnej waluty. Argumentował on również, że nie ma żadnych decydujących przesłanek, z powodu których należałoby dążyć za wszelką cenę do ujednolicenia granic wspólnego rynku, strefy euro i strefy Schengen.

Zdaniem Camerona rozczarowanie Brytyjczyków spowodowane było tym, iż wielu z nich myślało, że przystępują (jako kraj) do wspólnego rynku, a wstąpili do unii politycznej.

Jak się wydaje, tezy Camerona obliczone były przede wszystkim na potrzeby uprawiania polityki wewnętrznej. Weryfikując supozycje własnej polityki, starał się przede wszystkim odwrócić tendencje spadkowe w sondażach. Premier nie był zwolennikiem wyjścia Wielkiej Brytanii z UE, argumentując, że to eurosceptycy są przekonani, iż Unii nie da się zreformować, więc trzeba ją opuścić. On sam twierdził jednak, że możliwe są zmiany jej organizacji, a wyjście może wyraźnie zaszkodzić interesom Zjednoczonego Królestwa.

W świecie polityki pojawiały się głosy, jakoby Cameron starał się uzyskać poparcie kanclerz Niemiec Angeli Merkel dla koncepcji Europy dwóch prędkości, która zarówno wtedy, jak i dziś wydaje się w dużym stopniu nieunikniona. Pomysł ten prowadziłby jednak do oddalenia się od obecnego wzoru integracji europejskiej. Jednak czy już tak nie jest? Czyż nie mamy Europy dwóch prędkości?

Kluczowym i namacalnym posunięciem brytyjskiego rządu w kwestii reformy Unii był przegląd prawa - dogłębna analiza sytuacji legislacyjnej dotycząca całokształtu działalności Unii Europejskiej. Aby było to możliwe, Cameron wystosował konsultacyjne zagadnienia skierowane do pozostałych rządów członkowskich. Jednak reakcja rządów niemieckiego i francuskiego była niezadowalająca, ponieważ nie odpowiedziały one na owo zapytanie, nazywając je kwestionariuszem. Późniejszą inicjatywą była koncepcja tak zwanej czerwonej kartki. Została przedstawiona przez brytyjskiego ministra spraw zagranicznych 1 czerwca 2013 roku w Berlinie. Jej idea polegała na tym, iż parlamentom krajowym nadawano prawa weta wobec wszystkich 
aktów prawnych wydawanych przez instytucje europejskiej. Urzeczywistnienie tejże propozycji byłoby przełomową zmianą w Unii Europejskiej i odwróceniem dotychczasowego biegu integracji europejskiej (Czapniewski, 2013: 5).

\section{Zakończenie}

Wspominając postać byłego premiera, należy zauważyć, iż Cameron był ambitnym, zdeterminowanym politykiem, doskonale wykształconym i chyba nieźle przygotowanym do roli premiera. Miał za sobą wiele lat pracy jako polityczny adiutant czołowych polityków prawicy, menedżer w dużej prywatnej telewizji, deputowany do Izby Gmin. Na parlamentarnym etapie kariery przeskoczył w ciągu zaledwie czterech lat z poziomu zwykłego posła do pozycji lidera partii i opozycji. Nie przeszkodziło mu $\mathrm{w}$ tym to, że pochodził z bardzo zamożnej rodziny spokrewnionej z królem Williamem IV, a jego żona (o bardziej liberalnych poglądach) też należała do klasy wyższej (majątek obojga szacowano na minimum $3 \mathrm{mln}$, a maksimum $30 \mathrm{mln}$ funtów). Mimo przekonania, że społeczeństwo brytyjskie nie akceptuje elit, z reguły tej wyłamywał się wizerunek premiera. Cameron ujmował wielu faktem, że nie udawał kogoś, kim nie był, a z wyborcami miał łatwy i dobry kontakt. Budził też sympatię i szacunek przywiązaniem do swej rodziny, która wystawiona została na ciężką próbę, gdy okazało się, że pierwsze z trojga dzieci Cameronów urodziło się upośledzone. Cameron opiekował się chłopcem w każdej wolnej chwili, spędzając niekiedy w szpitalu całe noce. Podkreślał, że kocha go tak samo mocno jak drugiego synka i córeczkę. Gdy siedmioletnie chore dziecko zmarło w lutym 2009 roku, nawet politycy rządzącej ówcześnie Partii Pracy z Gordonem Brownem na czele wyrażali Cameronom współczucie równie serdecznie jak konserwatyści. A przecież to Cameron nazwał Browna pogardliwie politykiem analogowym w epoce cyfrowej. Zasłynął też z odzywki do Tony’ego Blaira: „kiedyś uosabiał pan przyszłość”. Kto wie, kiedy i od kogo sam usłyszy swoje własne Mane, tekel, fares (Szostkiewicz, 2010).

Zdając sobie sprawę z tego, że osoba Camerona budziła i budzi wiele kontrowersji, raz jeszcze należałoby podkreślić, iż zdaniem wielu miał on w sobie ogromną charyzmę, która pozwoliła mu na doprowadzenie swej partii do wygrania wyborów. Niektórzy jednak twierdzili i twierdzą, że premier Cameron obiecywał Wielkiej Brytanii podróż w nieznane. Nieznana ta to dzisiejszy wynik obiecanego przez niego referendum dotyczącego wyjścia UK z Unii, a co za tym idzie sytuacji (zarówno politycznej, jak i gospodarczej) Zjednoczonego Królestwa. 


\section{Bibliografia}

Biskup P. (2013), Integracja czy dezintegracja? Przyszłość Unii Europejskiej z perspektywy brytyjskiej, „Analiza Natolińska”, nr 5/63.

Brytyjski polityk bohaterem skandalu z marihuana (2007), http://www.monar.net.pl/ Article1332.html [dostęp: 15.05.2021].

Cameron D. (2006), KGB tried to recruit me, http://news.bbc.co.uk/2/hi/uk news/ politics/5021166.stm [dostęp: 5.01.2015].

Cameron D. (2010a), My vision, your choice, „The Daily Telegraph”, 3.04.2010.

Cameron D. (2010b), The Big Society, https://conservative-speeches.sayit.mysociety. org/speech/601246 [dostęp: 15.05.2021].

Czapniewski T. (2013), Reformator czy uciekinier? Rzad Davida Camerona wobec Unii Europejskiej i niemieckiego przywództwa, „Biuletyn Instytutu Zachodniego", nr 133.

David Cameron (2013), https://www.forbes.pl/sylwetka/david-cameron [dostęp: 15.10.2014].

Dorey P. (2007), A New Direction or Another False Down? David Cameron and the Crisis of British Conservatism, „British Politics”, nr 2.

Dulęba Ł. (2012), Ewolucja ideologiczna Partii Konserwatywnej w Wielkiej Brytanii w latach 2005-2012, „Środkowoeuropejskie Studia Polityczne”, t. 2.

Elliott F., Hanning J. (2012), Cameron. Practically a Conservative, Fourth Estate, London.

EU speech at Bloomberg (2013), https://www.gov.uk/government/speeches/eu -speech-at-bloomberg [dostęp: 16.05.2021].

Lee S. (2009), Introduction: David Cameron's Political Challenges, [w:] S. Lee, M. Beech (red.), The Conservatives under David Cameron: Built to Last?, Palgrave Macmillan, Basingstooke.

Nowicki M. (2015), Świnia polityczna, https://www.newsweek.pl/swiat/skandale -obyczajowe-w-brytyjskiej-polityce/67yy346 [dostęp: 26.10.2015].

Ostrowski M. (2014), Dwie batalia Davida Camerona, https://www.polityka.pl/tygodnikpolityka/swiat/1603563,1,dwie-batalie-davida-camerona.read [dostęp: 28.12.2014].

Pawlicki J. (2012), David Cameron, czyli polityczny survival, https:/wyborcza. pl/7,75399,11431789, david-cameron-czyli-polityczny-survival.html [dostęp: 10.12.2021].

Results \& Constituencies (b.r.), BBC News, http://news.bbc.co.uk/hi/english/ static/vote2001/results_constituencies/constituencies/637.stm [dostęp: 10.12.2021].

Rybarczyk M. (2010), David Cameron, nowy premier Wielkiej Brytanii z Oksfordu, https://www.newsweek.pl/swiat/david-cameron-nowy-premier-wielkiejbrytanii-cameron-premier/1wytrx0 [dostęp: 16.05.2021]. 
Szostkiewicz A. (2010), David Cameron, http://www.polityka.pl/tygodnikpolityka/ swiat/1501819,1,david-cameron.read [dostęp: 16.05.2021].

Wheeler B. (2005), The David Cameron story, http://news.bbc.co.uk/2/hi/uk_news/ politics/4502656.stm [dostęp: 7.12.2014].

Widzyk A. (2005), David Cameron nowym przywódca konserwatystów, https:// wiadomosci.wp.pl/david-cameron-nowym-przywodca-konserwatystow -6039128087810689a [dostęp: 15.10.2014].

Zuba K. (2012), Brytyjski system partyjny w XXI wieku - ciaglość czy zmiana?, „Annales Universitatis Mariae Curie-Skłodowska. Sectio K, Politologia”, vol. 19(1).

\section{Summary \\ Who was David Cameron? A political profile of the former Prime Minister}

This article discusses David Cameron both as politician and personality. Additionally, the author presents theses concerning the pragmatic nature of Cameron's policy as well as the Tories' departure from Margaret Thatcher's political line with the new Prime Minister, and the shift of Great Britain's activities to completely different areas of domestic and foreign policy. A secondary goal is to indicate the consequences of Cameron's policy for the external environment, primarily the cohesion of the European Union, but also - in the context of immigration policy for the countries of the young EU.

Keywords: David Cameron, political, profile, Prime Minister, views, reforms 